\title{
DISSOLVED COPPER SPECIATION BEHAVIOUR DURING ESTUARINE MIXING IN THE SAN SIMON INLET (WET SEASON, GALICIA). INFLUENCE OF PARTICULATE MATTER.
}

Juan Santos-Echeandia ${ }^{12 *}$, Luis M. Laglera ${ }^{1}$, Ricardo Prego ${ }^{2}$, Constant M.G. van den Berg ${ }^{1}$

\footnotetext{
${ }^{1}$ Department of Earth \& Ocean Sciences, Univers ity of Liverpool, Liverpool, L69 3GP, United Kingdom.

${ }^{2}$ Marine Biogeochemis try Research Group, Ins tituto de Investigaciones Marinas (CSIC), Vigo 36208, Spain.

*Communic ating author: jus ae@iim.csic.es
}

\begin{abstract}
The speciation trend of dissolved copper ( $\mathrm{DCu}$ ) was studied by first time in a Galician Ria across the estuarine zone of the Vigo Ria during the wet season and related to the copper levels in suspended particulate matter $(\mathrm{PCu})$ and sediments. In the riverine and ocean end-members DCu concentrations can be defined as pristine $(<4 \mathrm{nM}$ in Oitavén River). $\mathrm{DCu}$ is not conservative during the estuarine mixing and its concentration increase (5-8 $\mathrm{nM})$ cannot be only associated to $\mathrm{PCu}(0.5-1.0 \mathrm{nM})$ variations and the ria sediments may be an important DCu source. DCu speciation was mainly controlled by two types of ligands $\left(\log \mathrm{K}_{\mathrm{L} 1}^{\prime}=12.9-13.9 ; \log \mathrm{K}_{\mathrm{L} 2}^{\prime}=10.8-12.1\right)$. In all samples the concentration of $\mathrm{L}_{1}$ $\left(\mathrm{C}_{\mathrm{L} 1}=15-34 \mathrm{nM}\right)$ was greater than that of copper, which speciation is so dominated by this strong organic ligand. The transport of copper contamination from the middle Ria to the San Simon Inlet is limited during the wet season: in spite of similar salinities, $\mathrm{DCu}$ in the Inlet ( $6 \mathrm{nM})$ was much lower than at Rande Strait (15 nM).
\end{abstract}

Keywords: copper, speciation, water, SPM, sediments, ria, Galicia, Spain.

\section{INTRODUCTION}

The biogeochemical cycles of trace metals as copper are affected by the mixing process between the different phases, i.e. dissolved-SPM-sediment and chemical species. In the simplest situation river waters are gradually mixed in the estuary with seawater generally causing a dilution of trace metal concentrations. Several studies have demonstrated that dissolved copper shows a net increase in the estuary which can be due to: (1) mobilization of copper from riverine SPM during the estuarine mixing (Zwolsman et al., 1997; Nolting et al., 1999; Martino et al., 2002; Robert et al., 2004), (2) mobilization of copper from resuspended sediments (Lapp and Balzer, 1993; Pau cot and Wollast, 1997), (3) inputs of dissolved copper from interstitial waters in the sediments (Byrd and Andreae, 1986) and (4) other localised inputs as industrial activities usually (Turner, 1999). 
However, there are major rivers like the Miss is sippi where copper behaves conservatively (Shiller and Boyle, 1991).

Speciation studies have shown that copper tend to occur complexed by organic matter in estuarine waters and that this complexation may affect its geochemistry through control of the rate of scavenging, thus increasing their residence time in the estuary (van den Berg et al., 1987). The complexation also changes the bioavailability to organisms. It is therefore important to determine the chemical speciation of copper in addition to their partitioning across dissolved and particulate fractions, and the fraction in the sediments available for exchanging. It will be demonstrated that not only the strongest organic ligands but also the weakest ones play a very important role in diminishing the toxicity of the estuarine waters as pointed out before in the San Francisco Bay waters (Buck and Bruland, 2005).

An important lack of studies about copper speciation in a ria system has been reported in a recent review (Prego and Cobelo-Garcia, 2003) and only total dissolved copper levels have been investigated during the estuarine mixing of a Galician Ria (Cobelo-Garcia and Prego, 2003; Cobelo-Garcia and Prego, 2004a). Any toxic effects of copper could have serious implications to local mussel mariculture (Galician Rias produces $\sim 250,000$ ton of mussel per year, about $50 \%$ of the European production; Smaal, 2002) and it is of special interest a monitoring of the toxic species of this metal such as its free ion (Brand et al., 1986). Thus, the objective of this article is investigating the conservative pattern of dissolved copper and its speciation along the salinity gradient in a ria system: the Vigo Ria. The main tributary to the Vigo Ria is the Oitaven River (annual average flow of $17 \mathrm{~m}^{3} \cdot \mathrm{s}^{-1}$ and during the dry season is lower than $3 \mathrm{~m}^{3} \cdot \mathrm{s}^{-1}$ ) that runs the $85 \%$ of the total freshwater arriving the ria; so, during the low river waters the estuarine mixing has very scarce importance looking at the Vigo Ria and it must be studied in the wet season. Previous works in estuarine waters rich in SPM indicated that the metal concentration is mostly controlled by interactions with the SPM (Martino et al., 2002). In the Vigo Ria the levels of SPM are low (Prego et al., 2006) so its role must be clarified. This study will be of interest for future research in this type of estuaries were mariculture is one of the main activities developed on them.

\section{MATERIAL AND METHODS}

\subsection{Sampling}


Employing trace metal techniques, eight surface water samples were collected along the axial salinity gradient of the Vigo Ria on $16^{\text {th }}$ December 2004 following the winter estuarine mixing in counter-current during high tide (Fig.1). Sample locations were chosen to reflect the whole salinity gradient (values in table 1). The narrow channel formed by the river Oitavén was covered by sampling stations A to E. The mouth of the channel is usually affected by saline water even at low tide and due to the effect of the pillars of three bridges a local resuspension of sediments may occur. San Simon Inlet was covered by sampling stations $\mathrm{F}$ and $\mathrm{G}$. The bottom slopes down from a depth of $\sim 5 \mathrm{~m}$ near the Oitavén mouth to a depth of $25 \mathrm{~m}$ near the Rande Strait (station H) where there is a motorway bridge.

A telescopic pole with a bottle holder and sensors for in situ analys is of salinity, $\mathrm{pH}$ and temperature was attached to a raft and u sed to collect water samples. All samples were taken in polyethylene bottles which had been acid-washed and rinsed with Milli- $\mathrm{Q}^{50}$ water. Prior to filling with sample, the bottles were conditioned three times with the same water. On the same day, samples were filtered in the IIM-CSIC laboratories through a $0.2 \mu \mathrm{M}$ polypropylene Nuclepore filter inside class 100 laminar flow hood in a "ultra-clean" laboratory class 1000 lab to avoid contamination. Filtrates and filters were frozen and stored at $-20^{\circ} \mathrm{C}$ until dissolved and particulate copper analysis.

The deposition of copper on the San Simón Inlet was studied by sampling its sediments on 18 May 2005 using a Van Veen grab from the auxiliary raft of the RV Mytilus. Samples corresponded to the most surface sediment ( $<1 \mathrm{~cm}$ depth) at the locations in Fig.1. Samples were stored in acid-cleaned polyethylene vials, oven-dried $\left(50^{\circ} \mathrm{C}\right)$ and sieved using $63 \mu \mathrm{m}$ nylon meshes; the percentage of this fraction in the surface sediment is shown in the Figure 1.

\subsection{Analysis}

Total dissolved copper concentration in the filtered samples was determined as Campos and van den Berg (1994). Seawater was UV-digested after acidification to pH 2.2 with $\mathrm{HCl}$ in acid cleaned silica tubes. A $10 \mathrm{ml}$ sample aliquot was pipetted into the voltammetric cell and ammonia was added to approximately neutralise the $\mathrm{pH}$; HEPES buffer and SA were added. Copper analyses were carried out using voltammetric equipment consisting of an Autolab PGStat 10 voltammeter connected to a Metrohm VA 663 electrode stand, controlled by a computer. The reference electrode was double junction, $\mathrm{Ag} / \mathrm{AgCl}, \mathrm{KCl}(3 \mathrm{M})$, saturated $\mathrm{AgCl}$, with a salt-bridge filled with $3 \mathrm{M} \mathrm{KCl}$, and 
the counter electrode was a glassy carbon rod. A hanging mercury drop electrode (HMDE) was used as the working electrode.

Copper complexing ligands titrations was similar to that described before (Campos and van den Berg, 1994). A 170-mL filtered sample was transferred to a polyethylene bottle and HEPES buffer and SA were added. $10-\mathrm{mL}$ aliquots were pipetted into 15, 30 $\mathrm{mL}$, polystyrene vials, previously spiked with copper to give a concentration range between 0 and up to $400 \mathrm{nM}$ added copper and allowed to equilibrate overnight at room temperature $\left(20^{\circ} \mathrm{C}\right)$. Prior to the first titration the tubes were conditioned twice with seawater containing the same range of copper concentrations.

The complexation of copper by salicylald oxime is affected by the major ions present in seawater and therefore depends on the salinity $(S)$ of the sample. Values for the stability constants of the complexes $\mathrm{CuSA}$ and $\mathrm{Cu}(\mathrm{SA})_{2}$ at each salinity were calculated from (Campos and van den Berg, 1994):

$$
\begin{aligned}
& \log \mathrm{K}_{\mathrm{CuSA}}^{\prime}=(10.12 \pm 0.03)-(0.37 \pm 0.02) \log \mathrm{S} \\
& \log \mathrm{B}_{\mathrm{Cu}(\mathrm{SA}) 2}^{\prime}=(15.78 \pm 0.08)-(0.53 \pm 0.07) \log \mathrm{S}
\end{aligned}
$$

Complexing capacities and conditional stability constants of the natural ligands of the samples were obtained by linear least regression of $[\mathrm{CuL}] /\left[\mathrm{Cu}_{\text {labile }}\right]$ vs $\left[\mathrm{Cu}_{\text {labile }}\right]$ as described before (Ruzic, 1982; van den Berg, 1982). The slope and Y-axis value of this plot allow estimation of the complexing capacity and the conditional stability constant of

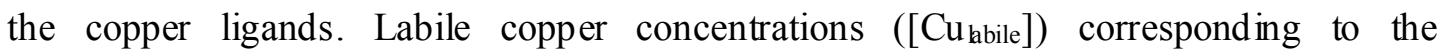
concentration of $\mathrm{Cu}(\mathrm{SA})_{2}$ were obtained from the peak heights of the voltammetric scans and the sensitivity. The concentration of organically complexed copper was calculated by subtraction of the labile from the total copper concentration in each aliquot. The sen sitivity of the CSV measurements was initially estimated from the linear part of the titration at high copper concen trations and corrected for underestimation using an iterative calculation similar to that used previously (Turoczy and Sherwood, 1997).

All the titration data sets showed curved relationships between $[\mathrm{CuL}] /\left[\mathrm{Cu}_{\text {labile }}\right]$ and $\left[\mathrm{Cu}_{\text {labile }}\right]$ indicating that more than one type of ligand classes was present with differing complex stability. Copper complexing ligand concentrations $\left(\mathrm{C}_{\mathrm{L} 1}\right.$ and $\left.\mathrm{C}_{\mathrm{L} 2}\right)$ and values for the conditional stability constants $\left(\mathrm{K}_{\mathrm{CuL} 1}^{\prime}\right.$ and $\left.\mathrm{K}_{\mathrm{CuL} 2}^{\prime}\right)$ on basis of $\mathrm{Cu}^{2+}$ were calculated as before (Laglera and van den Berg, 2003) by iterative fitting of the data to two complexing ligands.

Filters obtained from filtered water and sediment were digested in a microwave oven (Milestone MLS-1200 Mega) using Teflon bombs according to the EPA 3052 guideline 
method (Kingston, 1992). Then, copper determination was carried out by electrothermal atomic absorption spectroscopy (ETAAS) with Zeeman background correction (Varian 220). Aluminium concentrations were used to normalize copper concentrations in SPM samples. Its concentration was determined by means of flame atomic absorption spectroscopy (FAAS) using a Varian 220-FS apparatus. The analytical procedure was checked using the reference material PACS-1 (harbour marine sediment) giving good agreement with the certified values (error percentage respect to certified values always lower than $1.1 \%$ for $\mathrm{Cu}$ and $1.4 \%$ for $\mathrm{Al}$ ). With a fraction of the sediment sample, the exchangeable percentage of $\mathrm{Cu}$ was obtained by applying part of the $\mathrm{BCR}$ extraction

procedure (European Community Bureau of Reference; Quevauviller et al., 1997). It is used just the first step to provide the most labile fraction. Reference material (BCR 601) was used to certificate the quality of the analysis (error percentage in the range of $2.4 \%$ ).

\section{RESULTS}

The salinity, temperature and $\mathrm{pH}$ at the sampling stations is shown in Table 1 . The temperature at the river end-member $\left(9.4^{\circ} \mathrm{C}\right)$ was lower than the temperature at the seawater end $\left(13.4^{\circ} \mathrm{C}\right)$ showing temperature increase with the increase of salinity. The $\mathrm{pH}$ distribution reflects a similar pattern with values ranging from 6.5 at the freshwater end to $\sim 8.1$ at the high salinity end

$\mathrm{DCu}$, ligand concentrations and conditional stability constants are summarised in Table 1. DCu throughout the ria was in the range of 4 to $15 \mathrm{nM}$ (Table 1). The lowest value found corresponded to the Oitaven river waters (salinity 0) while in Rande Strait $\mathrm{DCu}$ concentrations were the highest $(15 \mathrm{nM})$. The data were fitted to two types of ligands, $\mathrm{L}_{1}$ and $\mathrm{L}_{2}$ (Fig.2). The strongest ligand $\left(\mathrm{L}_{1}\right)$ was present at concentrations in the range 15 to $34 \mathrm{nM}$. The concentration was fairly constant or with a little increase between salinities 0 and 20 but a sudden decay of $L_{1}$ was observed at salinity 24.6 that continues until salinity 35. The concentration of the second ligand $\left(\mathrm{L}_{2}\right)$ was generally greater than $\mathrm{L}_{1}$ ranging from $10 \mathrm{nM}$ to $96 \mathrm{nM}$. Higher values were present at low salinity waters decreasing towards the marine end-member. Values of $\log \mathrm{K}_{1}$ range between 12.9 and 13.9, with higher values in the lower salinity waters. The stability constants for the second ligand, $\log \mathrm{K}_{2}$ range between 10.8 and 12.1 also showing a general decrease from the low salinity end. Decreasing values of $\log \mathrm{K}$ with increasing salinity are expected as the copper complexation suffers increasingly from competition by the major cations. The $\mathrm{pCu}$ in the ria was found to vary between 12.5 and 14.6. The area around Rande is where the free 
copper ion concentration was the highest (12.5) due to a combination of weaker complexation (main effect due to saturation of $\mathrm{L}_{1}$ ) and higher copper concentrations.

The concentration of SPM and its content in particulate copper $(\mathrm{PCu})$ and aluminium are indicated in Table 2. SPM in the Vigo Ria varied between 0.8 and $3.6 \mathrm{mg} \mathrm{L}^{-}$

${ }^{1}$ (Table 2). In the inner estuary SPM decreases with increasing salinity up to $18 \mathrm{mg} \mathrm{L}^{-1}$, then SPM increases at salinities $20-33 \mathrm{mg} \mathrm{L}^{-1}$ decreasing again at station $\mathrm{H}$ (salinity 35 ) with $\sim 1 \mathrm{mg} \mathrm{L}^{-1}$. PCu showed a range of between 14 and $37 \mu \mathrm{gCu} \mathrm{g}^{-1}$ along the estuary with a slight decrease towards the high salinity end. Aluminium was determined in the SPM as a terrigenous source reference. It was in the range of 14 to $59 \mathrm{mgAl} \mathrm{g}^{-1}$ with a bulge-like trend.

The distribution of total copper in the fine fraction of the surface sediments is shown in Fig.3. The sedimentary copper concentrations in the sediments of the San Simon inlet increase from 23 to $40 \mu \mathrm{g} \mathrm{g}^{-1}$ in the innermost area to 60 to $120 \mu \mathrm{g} \mathrm{g}^{-1}$ in the Alvedosa River mouth. The labile concentration of copper in the sediments is generally low and follows a distribution similar to the total concentration (Fig.3). All the exchangeable copper concentrations are below $0.5 \%$ with the exception of the sediments close to the Alvedosa mouth which have values between 0.6 and $2.5 \%$.

\section{DISCUSSION}

The low part of the Oitaven River was characterised by salinities lower than 15 and $\mathrm{DCu}$ concentrations with a progressive but not pronounced increase from 4 to $6 \mathrm{nM}$ of $\mathrm{DCu}$ in the freshwater end-member (Fig.4a). This non-conservative trend is associated to a slight increase of the strongest ligands $\left(\mathrm{L}_{1}\right)$ (Fig. $4 \mathrm{~b}$ ) which implies both variables co-vary in this section of the estuarine mixing, as has been pointed out for the Scheldt estuary (van den Berg et al., 1987; Nolting et al., 1999). PCu showed an opposite trend to DCu (Fig.5) thus, an interchange between both phases may be occurring. However, $\mathrm{PCu}$ cannot be a significant contributor of copper to the dis solved phase because its concentration is less than the rise of dissolved one (Table 1). This leads to the assumption of sedimentary origin of DCu and ligands.

Salinity varied from 20 to 34 in the San Simon Inlet and SPM concentration were the highest measured. In this area of the ria, there are SPM inputs from Alvedosa River (Evans et al., 2003), and resuspension of fine particles (as result of the tide in the sallow waters; Mota et al., 2005), corroborated by Aluminium levels of SPM (Fig.5) and the sediment 
mud percentage (Fig.1). Therefore, DCu was keeping the non-conservative trend (Fig.4a) and its levels decrease down to the marine end-member concentration of 2-3 nM reported for North Atlantic (Campos and van den Berg, 1994) and the Western Galician Shelf seawaters (Santos Echeandia et al., 2005). Then, DCu and PCu increased in the San Simón water column as a probably consequence of resuspension of copper rich sediments (Cobelo-Garcia and Prego, 2004b) and pore water fluxes of copper (Shank et al., 2004). It is a new reason to considering the bulge-like copper distribution in rias proposed by Cobelo-Garcia and Prego (2004a).

The mouth of San Simon Inlet, i.e. the Rande Strait, presented a DCu concentration of $15 \mathrm{nM}$ and, lacking any chelation with organic ligands, the free copper would reach $\sim 10^{-}$ 8.9. This copper concentration may be considered as toxic (Brand et al., 1986) for some plankton species which feed the mussels cultivated in this area. Therefore, the Rande Strait may be a key part of the estuary. A ria transport model using tracking particles (GomezGesteira et al., 1999) predicted an accumulation of them in this area, leading so to contamination and sedimentation. This is corroborated by higher copper concentrations in the sediments and a strong SPM gradient within the San Simon inlet that suggests sedimentation as SPM does not reach off inlet. The strong gradient of total dissolved copper in the strait can be associated to scavenging by the strong sedimentation of SPM and the biological filtration due to the mussel rafts placed close to the strait that eventually deposit metals as faecal pellets (Evans et al., 2003).

Dissolved copper behaviour along the estuarine mixing in the Vigo Ria can be defined as non-conservative with a slightly increased levels at mid salinities. This pattern has also been found in estuaries like the Scheldt (Zwolsman et al., 1997) and was thought to be mainly due to metal releases from sediments and SPM at mid salinities. The offshore ria seawater level of DCu (2-3 nM: Campos and van den Berg, 1994; Santos-Echeandía et al., 2005) becomes greatly enhanced by local inputs (harbour and shipyard activities) inside the ria (Prego et al., 2006). It is common in some estuaries (Helz et al., 1975; Turner, 1999), but the estuarine zone in the Western Galician Rias is normally placed in the innermost ria (Evans and Prego, 2003). It is different of the typical estuarine coastal systems, so in the Vigo Ria the estuarine mixing is usually located in the low part of the Oitavén River and the San Simón Inlet during the wet season.

For this reason and the Rande Strait influence already explained in this section, the transport of copper contamination from the middle Ria to the San Simon Inlet is limited during the wet season: in spite of similar salinities, $\mathrm{DCu}$ in the Inlet was much lower than 
at Rande Strait (Table 1). Similar pattern was observed for the strongest complexing ligand $\left(\mathrm{L}_{1}\right)$ along the estuary (Figure $4 \mathrm{~b}$ ). Compared to the linear dilution line $\mathrm{L}_{1}$ showed a midestuarine maximum suggesting that the mid-estuarine copper release was in complexed form. A possible source could be the sediments, according to the observed in laboratory experiments with the resuspended matter of San Simon Inlet (Cobelo-García and Prego, 2004b) and in other estuaries (Shank et al., 2004; Mota et al., 2005). On the contrary, the weaker ligand $\left(\mathrm{L}_{2}\right)$ seems to be less affected by other parallel processes apart from the simple dilution of the waters (i.e. resuspension) occurring during the estuarine mixing (Fig 4c). The concentration of $\mathrm{L}_{1}$ was generally much greater than that for $\mathrm{DCu}$, so the copper speciation is largely determined by this ligand in the ria case.

Aknowle dgements. The authors would like to thank Mr. Ricardo Casal assistance with the Ria sampling, Ana Filgueira and Clemente Trujillo for copper analyses of the sediments and suspended matter and Paula Ferro for technical assistance. The visit of J. SantosEcheandia was financially supported by a Marie Curie Training Fellowship of the EU (contract No HPMT-CT-2001-00218) to the Marine Electrochemistry Group of the Department of Earth and Ocean Sciences (University of Liverpool). J. Santos-Echeandía thanks the Basque Government for financial support (pre-doctoral grant). The Spanish research was funded by the CICYT coordinated project "Biogeochemical budget and modelling of metal fluxes in a Galician ria (METRIA)", ref. REN2003-04106-C03.

\section{REFERENCES}

Brand, L.E., Sunda, W.G. and Guillard, R.R.L., 1986. Reduction of marine-phytoplankton reproduction rates by copper and cadmium. Journal of Experimental Marine Biology and Ecology 96, 225-250.

Byrd, J.D. and Andreae, M.O., 1986. Geochemistry of tin in rivers and estuaries. Geochimica et Cosmochimica Acta 50, 835-845.

Buck, K. and Bruland, K., 2005. Copper speciation in San Francisco Bay: A novel approach using multiple analytical windows. Marine Chemistry 96, 185-198.

Campos, M.L.A.M. and van den Berg, C.M.G., 1994. Determination of copper complexation in sea water by cathodic stripping voltammetry and ligand competition with salicylaldoxime. Analytica Chimica Acta 284, $481-496$.

Cobelo-Garcia, A. and Prego, R., 2003. Land inputs, behaviour and contamination levels of copper in a ria estuary (NW Spain). Marine Environmental Research 56, 403-422.

Cobelo-Garcia, A. and Prego, R., 2004a. Behaviour of dissolved Cd, $\mathrm{Cu}, \mathrm{Pb}$ and $\mathrm{Zn}$ in the estuarine zone of the Ferrol Ria (Galicia, NW Iberian Peninsula). Fresenius Environmental Bulletin 13, 753-759.

Cobelo-Garcia, A. and Prego, R., 2004b. Chemical speciation of dissolved copper, lead and zinc in a ria coastal system: The role of resuspended sediments. Analytica Chimica Acta 524, 109-114.

Evans, G., Howarth, R.J. and Nombela, M.A., 2003. Metals in the sediments of Ensenada de San Simon (inner Ria de Vigo), Galicia, NW Spain. Applied Geochemistry 18, 973-996. 
Evans, G. and Prego, R. (2003). Rias, estuaries and incised valleys: is a ria an estuary?. Marine Geology 196, 171-175.

Gomez-Gesteira, M., Montero, P., Prego, R., Taboada, J.J., Leitao, P., Ruiz-Villarreal, M., neves, R. and Perez-Villar, V., 1999. A two-dimensional particle tracking model for pollution dispersion in A Coruña and Vigo Rias (NW Spain). Oceanologica Acta 22, 166-177.

Helz, G.R., Huggett, R.J. and Hill, J.M., 1975. Behavior of Mn, Fe, Cu, Zn, Cd and Pb Discharged from a Wastewater Treatment Plant into an Estuarine Environment. Water Research 9, 631636.

Kingston, H.M., Walter, P.J., 1992. Comparison of Microwave verses Conventional Dissolution for Environmental Applications. Spectroscopy 7, 20-27.

Laglera, L.M. and van den Berg, C.M.G., 2003. Copper complexation by thiol compounds in estuarine waters. Marine Chemistry 82, 71-89.

Lapp, B. and Balzer, W., 1993. Early diagenesis of trace metals used as an indicator of past productivity changes in coastal sediments. Geochimica et Cosmochimica Acta 57, 4639-4652.

Martino, M., Turner, A., Nimmo, M. and Millward, G.E., 2002. Resuspension, reactivity and recycling of trace metals in the Mersey Estuary, UK. Marine Chemistry 77, 171-186.

Mota, A.M., Cruz, P., Vilhena, C. and Goncalves, M.L.S., 2005. Influence of the sediment on lead speciation in the Tagus estuary. Water Research 39, 1451-1460.

Nolting, R.F., Helder, W., de Baar, H.J.W. and Gerringa, L.J.A., 1999. Contrasting behaviour of trace metals in the Scheldt estuary in 1978 compared to recent years. Journal of Sea Research 42, 275-290.

Paucot, H. and Wollast, R., 1997. Transport and transformation of trace metals in the Scheldt estuary. Marine Chemistry 58, 229-244.

Prego, R. and Cobelo-Garcia, A., 2003. Twentieth century overview of heavy metals in the Galician Rias (NW Iberian Peninsula). Environmental Pollution 121, 425-452.

Prego, R., Cotte, M.H., Cobelo-Garcia, A., and Martin, J.M., 2006. Trace metals in the water column of the Vigo Ria: Offshore exchange in mid-winter conditions. Estuarine Coastal and Shelf Science 68, 289-296.

Quevauviller, P., Rauret, G., Rubio, R., LopezSanchez, J.F., Ure, A., Bacon, J. and Muntau, H., 1997. Certified reference materials for the quality control of EDTA- and acetic acid-extractable contents of trace elements in sewage sludge amended soils (CRMs 483 and 484). Fresenius Journal Of Analytical Chemistry 357, 611-618.

Robert, S., Blanc, G., Schafer, J., Lavaux, G. and Abril, G., 2004. Metal mobilization in the Gironde Estuary (France): the role of the soft mud layer in the maximum turbidity zone. Marine Chemistry 87, 1-13.

Ruzic, I., 1982. Theoretical aspects of the direct titration of natural waters and its information yield for trace metal speciation. Analytica Chimica Acta 140,99-113.

Santos-Echeandia, J., Prego, R. and Cobelo-Garcia, A., 2005. Copper, nickel, and vanadium in the Western Galician Shelf in early spring after the Prestige catastrophe: Is there seawater contamination? Analytical and Bioanalytical Chemistry 382, 360-365.

Shank, G.C., Skrabal, S.A., Whitehead, R.F., and Kieber, R.J., 2004. Fluxes of strong Cucomplexing ligands from sediments of an organic-rich estuary. Estuarine, Coastal and Shelf Science 60,349-358.

Shiller, A.M. and Boyle, E.A., 1991. Trace elements in the Mississippi River Delta outflow region: behavior at high discharge. Geochimica et Cosmochimica Acta 55, 3241-3251.

Sholkovitz, E.R., 1976. Flocculation of dissolved organic and inorganic matter during mixing of river water and seawater. Geochimica et Cosmochimica Acta 40, 831-845.

Smaal, A.C., 2002. European mussel cultivation along the Atlantic coast: production status, problems and perspectives. Hyd robio logia 484, 89-98.

Turner, A., 1999. Diagnosis of chemical reactivity and pollution sources from particulate trace metal distributions in estuaries. Estuarine Coastal And Shelf Science 48, 177-191.

Turoczy, N.J. and Sherwood, J.E., 1997. Modification of the van den Berg/Ruzic method for the investigation of complexation parameters of natural waters. Analytica Chimica Acta 354, 15 21. 
van den Berg, C.M.G., 1982. Determination of copper complexation with natural organic ligands in seawater by equilibration with $\mathrm{MnO} 2 \mathrm{I}$. Theory. Marine Chemistry 11,307-322.

van den Berg, C.M.G., Merks, A.G.A. and Duursma, E.K., 1987. Organic complexation and its control of the dissolved concentrations of copper and zinc in the Scheldt estuary. Estuarine, Coastal and Shelf Science 24, 785.

Zwolsman, J.J.G., Van Eck, B.T.M. and Van der Weijden, C.H., 1997. Geochemistry of dissolved trace metals (cadmium, copper, zinc) in the Scheldt estuary, southwestern Netherlands: Impact of seasonal variability. Geochimica Et Cosmochimica Acta 61, 1635-1652. 


\section{Figure captions}

Figure 1. Bathymetric map and fine sediment percentage of the study area (San Simon Inlet) with the sampling points. Water sampling locations are represented by filled circles and sediment sampling positions with open circles. San Simón Inlet is a semiclosed mesotidal system of low hydrodynamic energy delimited by the River Oitaven outflow and the Rande Strait with a surface of $17 \mathrm{~km}^{2}$. It is a recognized mariculture area with many mussel rafts and sand banks where large quantities of shellfish are collected during the year.

Figure 2. Titration of the 20 salinity sample (station E). a) Peak current vs. added copper concentration. b) Linearisation of the data from which two types of ligands can be observed

Figure 3. Copper concentration in the surface sediment $(<63 \mu \mathrm{m}$ fraction) and its percentage of the labile fraction

Figure 4. Distribution of dissolved copper (a) and of the strong (b) and weak (c) copper complexing ligands $\left(\mathrm{L}_{1}\right.$ and $\left.\mathrm{L}_{2}\right)$ as a function of the salinity. Copper in North Atlantic Waters has been added and the lines in all the plots represent the hypothetical dilution line between the freshwater and marine end members.

Figure 5. Particulate copper and aluminium (nM) as a function of the salinity 
Fig.1

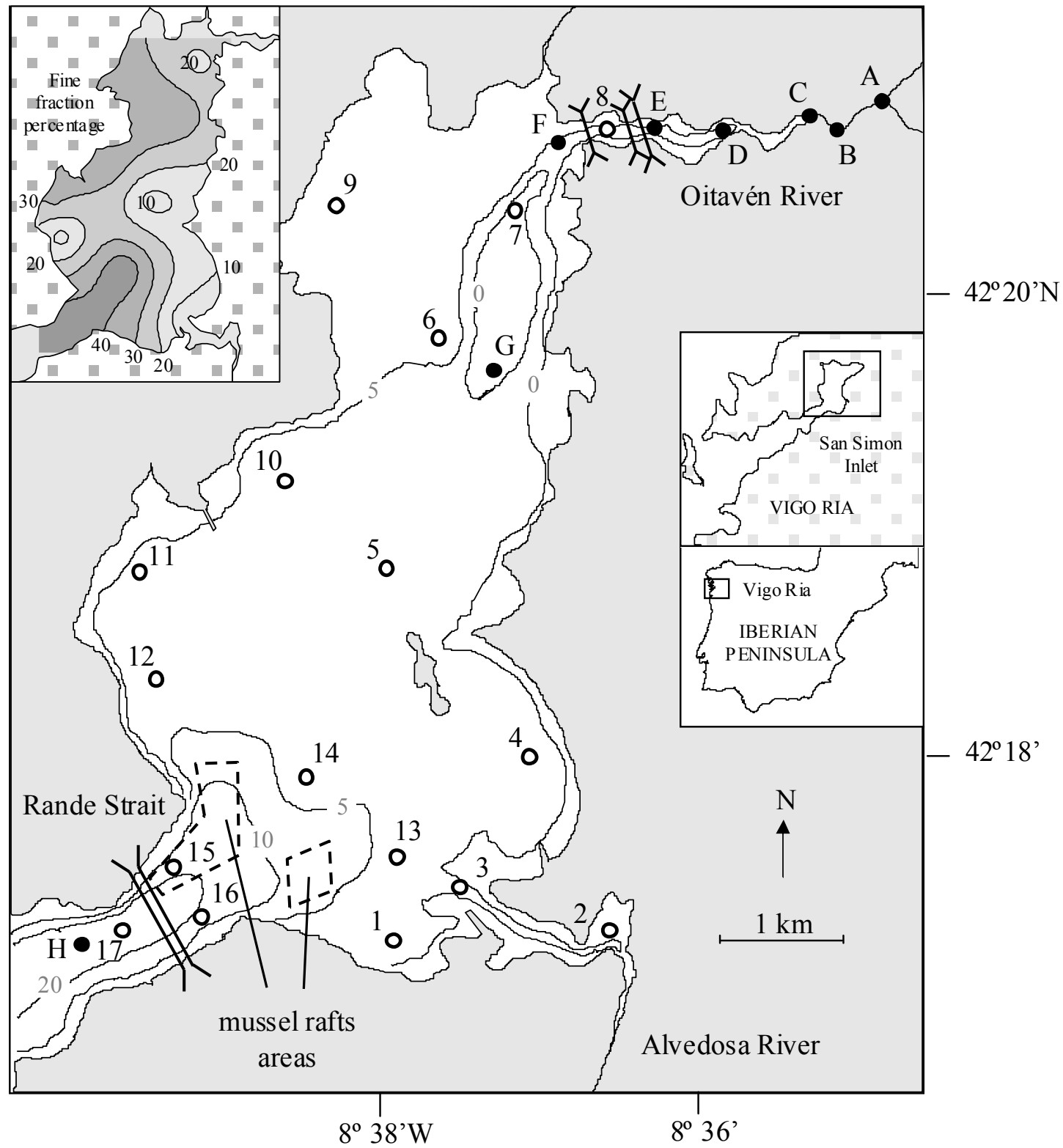


Fig.3
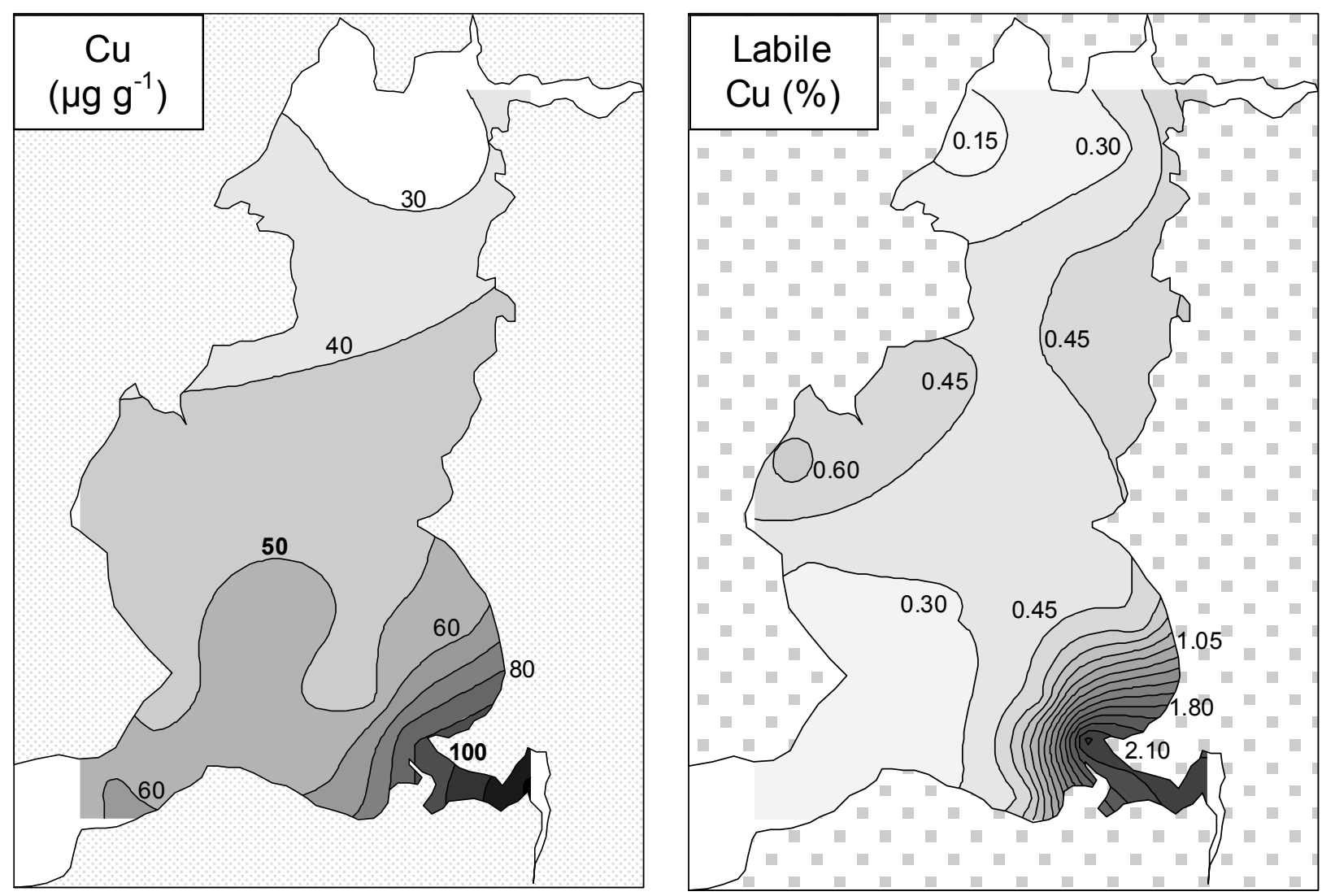
Fig.4
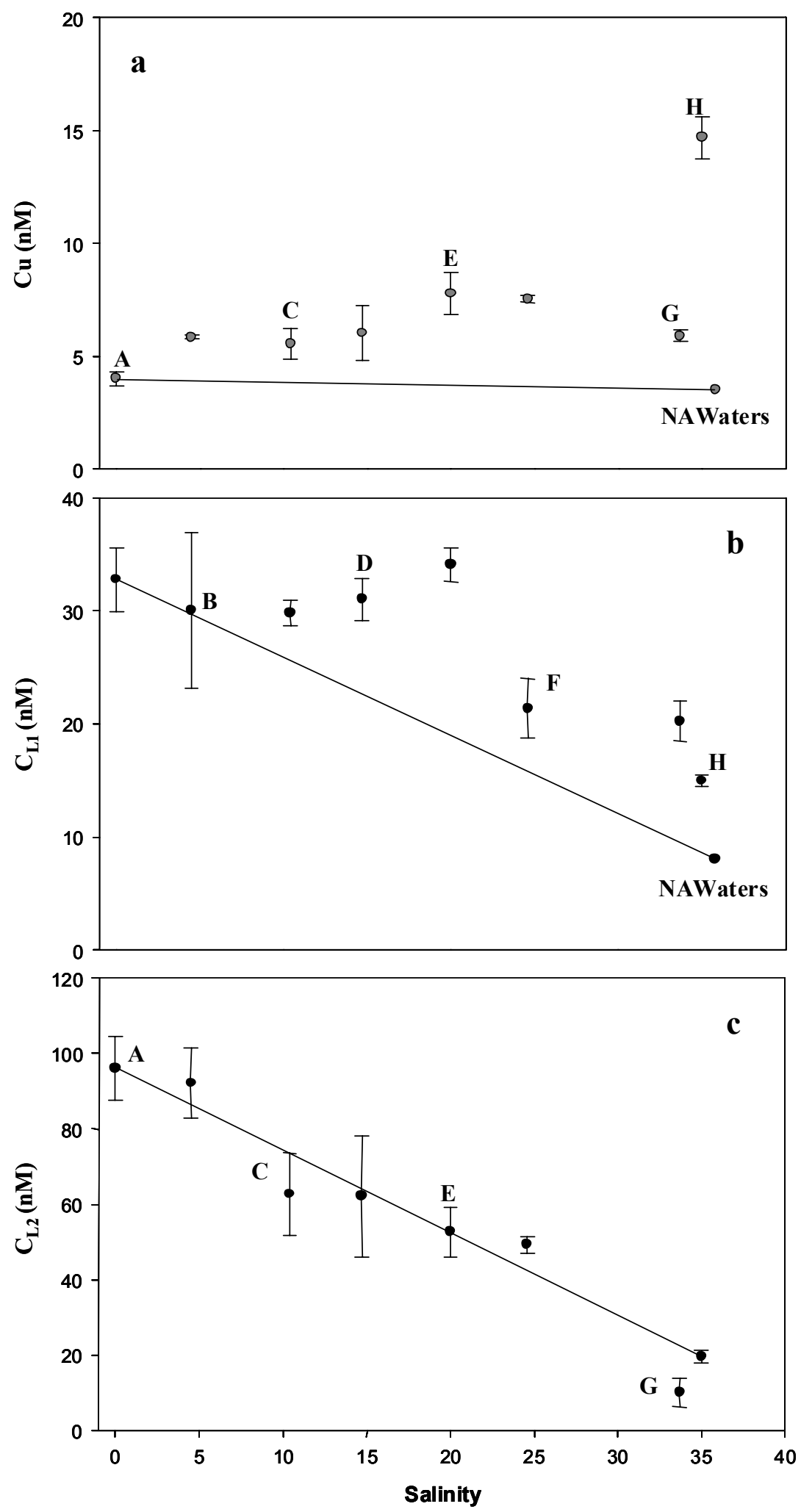
Fig. 5

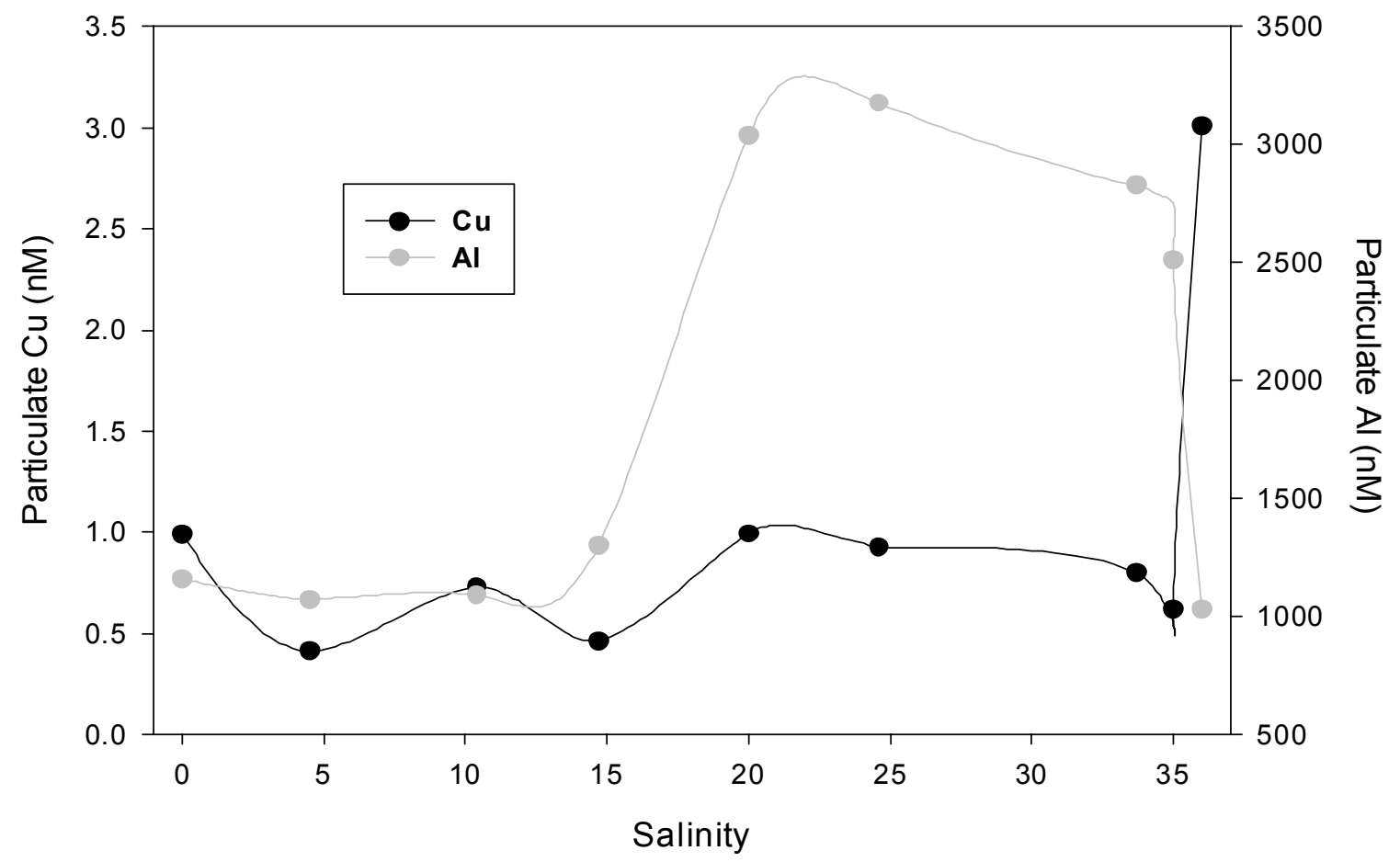


Table 1. Measured variables for the water sampling along the estuary in the points shown in Fig.1.

\begin{tabular}{|c|c|c|c|c|c|c|c|c|c|}
\hline Station & Salinity & Temp $\left({ }^{\circ} \mathrm{C}\right)$ & $\mathrm{pH}$ & $\mathrm{DCu}(\mathrm{nM})$ & $\mathrm{L}_{1}(\mathrm{nM})$ & $\log \mathrm{K}_{1}^{\prime}$ & $\mathrm{L}_{2}(\mathrm{nM})$ & $\log \mathrm{K}_{2}^{\prime}$ & $\mathrm{pCu}$ \\
\hline $\mathrm{A}$ & 0.0 & 9.4 & 6.50 & $4.0 \pm 0.2$ & $32.8 \pm 2.8$ & $13.70 \pm 0.10$ & $96 \pm 8.4$ & $12.1 \pm 0.2$ & 14.6 \\
\hline B & 4.5 & 9.6 & 7.02 & $5.9 \pm 0.1$ & $30.0 \pm 6.9$ & $13.50 \pm 0.13$ & $92 \pm 9.8$ & $11.5 \pm 0.1$ & 14.2 \\
\hline $\mathrm{C}$ & 10.4 & 10.1 & 7.27 & $5.6 \pm 0.7$ & $29.8 \pm 1.1$ & $13.08 \pm 0.03$ & $63 \pm 10.9$ & $11.1 \pm 0.1$ & 13.7 \\
\hline $\mathrm{D}$ & 14.7 & 10.4 & 7.24 & $6.0 \pm 1.2$ & $31.0 \pm 1.9$ & $13.15 \pm 0.05$ & $62 \pm 16.0$ & $11.3 \pm 0.3$ & 13.8 \\
\hline $\mathrm{E}$ & 20.0 & 10.8 & 7.96 & $7.8 \pm 0.9$ & $34.0 \pm 1.5$ & $12.87 \pm 0.04$ & $53 \pm 6.6$ & $10.8 \pm 0.6$ & 13.4 \\
\hline $\mathrm{F}$ & 24.6 & 11.2 & 7.98 & $7.6 \pm 0.2$ & $21.4 \pm 1.9$ & $13.90 \pm 0.30$ & $49 \pm 2.0$ & $11.7 \pm 0.2$ & 13.6 \\
\hline $\mathrm{G}$ & 33.7 & 12.1 & 7.96 & $5.9 \pm 0.3$ & $20.2 \pm 1.8$ & $12.92 \pm 0.08$ & $10 \pm 3.8$ & $11.8 \pm 0.5$ & 13.3 \\
\hline $\mathrm{H}$ & 35.0 & 12.1 & 7.99 & $14.7 \pm 0.9$ & $15.0 \pm 0.5$ & $13.43 \pm 0.05$ & $20 \pm 1.6$ & $11.4 \pm 0.1$ & 12.5 \\
\hline
\end{tabular}


Table 2. SPM levels and particulate copper and aluminium concentrations along the estuary in the points shown in Fig.1.

\begin{tabular}{ccccc}
\hline Station & $\mathrm{SPM}\left(\mathrm{mg} \mathrm{L}^{-1}\right)$ & $\mathrm{Cu}(\mathrm{nM})$ & $\mathrm{Cu}\left(\mu \mathrm{g} \mathrm{g}^{-1}\right)$ & $\mathrm{Al}_{\left(\mathrm{mg} \mathrm{g}^{-1}\right)}$ \\
\hline $\mathrm{A}$ & 2.31 & 0.99 & 27 & 14 \\
$\mathrm{~B}$ & 1.09 & 0.41 & 24 & 27 \\
$\mathrm{C}$ & 1.26 & 0.73 & 37 & 23 \\
$\mathrm{D}$ & 0.83 & 0.46 & 35 & 42 \\
$\mathrm{E}$ & 2.60 & 0.99 & 24 & 31 \\
$\mathrm{~F}$ & 2.14 & 0.93 & 27 & 40 \\
$\mathrm{G}$ & 3.58 & 0.80 & 14 & 21 \\
$\mathrm{H}$ & 1.10 & 0.62 & 34 & 59 \\
\hline
\end{tabular}

